\title{
Olhos e colhões: Da sexualidade à historicidade em História do olho*
}

\section{Luís Felipe Sobral**}

\section{Resumo}

História do olho, a novela pornográfica que Georges Bataille publicou sob pseudônimo em 1928, oferece diversos elementos ao debate sobre sexualidade, suas normas, transgressões $e$ transformações. Este artigo procura, contudo, demonstrar que a sexualidade encontra-se aí vinculada a uma noção bastante específica de historicidade, produzida pelas inovações literárias do entreguerras. Partindo da análise do episódio do acidente fatal sofrido pelo matador Manuel Granero, acompanha-se não somente o processo de redação da novela, mas também o percurso de deciframento psicanalítico percorrido pelo próprio Bataille, conduzindo assim a uma perspectiva histórica muito além do âmbito do desejo e da fantasia.

Palavras-chave: Georges Bataille (1897-1962), Corrida de Touros, Pornografia, Psicanálise, Historicidade.

* Recebido em 05 de junho de 2017, aceito em 10 de outubro de 2018.

** Professor Colaborador, Departamento de Antropologia da Unicamp, Campinas, SP, Brasil. If_sobral@yahoo.com / https://orcid.org/0000-0003-4380-3420 
Eyes and Balls: From Sexuality to Historicity in Story of the Eye

\begin{abstract}
Story of the Eye, the pornographic novella published by Georges Bataille under a pseudonym in 1928, offers several elements to the debate on sexuality, its norms, transgressions and transformations. However, this article seeks to demonstrate that the sexuality in the book is tied to a very specific notion of historicity, produced by the literary innovations of the interwar years. Based on an analysis of the episode of the fatal accident suffered by the matador Manuel Granero, the article follows not only the writing of the novella, but also the path of psychoanalytical deciphering taken by Bataille, leading to a historical perspective far beyond the realm of desire and fantasy.
\end{abstract}

Keywords: Georges Bataille (1897-1962), Bullfighting, Pornography, Psychoanalysis, Historicity. 
1.

Na novela História do olho, publicada em francês, em 1928, sem especificação de editora, e atribuída ao misterioso Lord Auch, o narrador anônimo relata suas aventuras eróticas juvenis com sua parceira Simone em um balneário não nomeado do litoral francês. Depois do suicídio de uma amiga, enlouquecida pelas orgias das quais participava com eles, os dois jovens partem à Espanha "para evitar o aborrecimento de um inquérito policial" (Bataille, 1970a:16) ${ }^{1}$. As atividades eróticas prosseguem além-Pireneus, contando agora com a participação de sir Edmond, um milionário inglês voyeur que se propõe a sustentar Simone. Esta adora as corridas de touros e aprecia especialmente a entrada impetuosa do touro na arena, os chifres da fera cravados no flanco das éguas e a queda, daí decorrente, de uma massa de entranhas por entre as pernas do animal. Ela assiste angustiada ao espetáculo, temendo, e ao mesmo tempo desejando, ver o toureiro ser arremessado no ar. Quando sir Edmond explica que era costume, entre os espanhóis viris, comer os colhões grelhados do primeiro touro ainda durante a tourada, Simone, fascinada, faz uma exigência inusitada: ela quer os colhões crus em um prato. Em 7 de maio de 1922, o trio vai à arena de Madri assistir ao toureio de Manuel Granero, que possui a reputação de ser um grande matador. Após a morte do primeiro touro pela espada de Granero, o narrador e Simone fornicam violentamente em um banheiro fétido; ao retornarem aos seus lugares, os colhões crus, "de uma brancura carminada, ligeiramente rosa de sangue, idêntica à do globo ocular" (Bataille, 1970a:54), aguardam Simone, que revela seu desejo de sentar-se sobre eles. $\mathrm{O}$ narrador continua:

É justo dizer que, ademais, a corrida tornara-se monótona, touros pouco combativos encontrando-se diante de matadores que não sabiam como manejá-los e, além disso, como Simone insistira para que nos sentássemos ao sol,

1 Salvo indicação contrária, todas as traduções são minhas. 
estávamos presos em uma espécie de imensa névoa de luz e calor úmido que ressecava a garganta e oprimia.

Era, de fato, completamente impossível que Simone levantasse seu vestido e sentasse seu traseiro nu no prato de colhões crus. Ela devia restringir-se a manter esse prato sobre os joelhos. Eu lhe disse que queria foder mais uma vez antes do retorno de Granero, que devia combater somente o quarto touro, mas ela recusou e permaneceu lá, vivamente interessada, apesar do estripamento dos cavalos, seguido, como ela dizia infantilmente, das "perdas $e$ danos", isto é, da cachoeira de entranhas.

A irradiação solar nos absorvia pouco a pouco em uma irrealidade bem conforme ao nosso mal-estar, isto é, à vontade muda e impotente de arrebentar e revirar os cus. Fazíamos uma careta provocada ao mesmo tempo pela cegueira, pela sede e pela perturbação dos sentidos, incapazes também de nos desafogarmos. Conseguíramos compartilhar em três a deliquescência morosa, na qual não há mais nenhuma concordância das diversas contrações do corpo, a tal ponto que o retorno de Granero não foi capaz de nos tirar dessa absorção embrutecedora. Além disso, o touro que se encontrava diante dele era desconfiado $e$ parecia pouco nervoso: a corrida prosseguia de fato sem mais interesse que antes.

Os acontecimentos que seguiram produziram-se sem transição e como que sem vínculo, não porque eles não estavam realmente ligados, mas porque minha atenção, como que ausente, permanecia absolutamente dissociada. Em poucos instantes, vi primeiro Simone morder, para meu espanto, um dos colhões crus, depois Granero avançar em direção ao touro, apresentando-lhe o pano escarlate enfim, quase ao mesmo tempo, Simone, com o sangue à cabeça e um despudor sufocante, descobriu suas longas coxas brancas até a vulva úmida, onde ela fez entrar lenta e seguramente o segundo glóbulo pálido - Granero revirado pelo touro e acuado contra a balaustrada; sobre essa balaustrada, os chifres o golpearam três vezes com toda força $e$, no terceiro golpe, um chifre arrombou o olho direito e toda a cabeça. Um imenso grito de horror coincidiu com um orgasmo breve de Simone, que foi 
levantada da laje de pedra e caiu para trás com o nariz sangrando, tudo isso sob um sol ofuscante; acorreu-se o quanto antes para levar nos braços o cadáver de Granero, cujo olho direito pendia da cabeça (Bataille, 1970a:55)2.

O clímax da cena é produzido pela alternância entre duas séries de eventos: na arquibancada, Simone morde um dos colhões crus, descobre as coxas, introduz o outro colhão em sua vagina, goza e tomba com o nariz sangrando; na arena, Granero aproxima-se do touro, tem seu corpo arremessado pelo animal e seu olho direito perfurado pelo chifre, provocando um grito de horror na multidão. Tais séries encontram-se apartadas da perspectiva cognitiva, pois prevalece uma sensação de irrealidade produzida por vários elementos vulgares capazes de entorpecer os sentidos: a monotonia da corrida, a opressão solar, o desejo sexual incontrolável, o estripamento dos cavalos, a deformação das expressões faciais. Ainda assim, o narrador garante a existência de um vínculo entre as séries, que se correspondem analogicamente conforme seus elementos são intercalados, culminando na penetração simultânea da cavidade vaginal pelo colhão e da cavidade ocular pelo chifre, associação da perversão de Simone ao infortúnio de Granero, da sexualidade à morte. A eficácia desse procedimento, construído em torno da afinidade morfológica entre os olhos e os colhões, repousa, portanto, na serialização de traços grotescos que conduz irremediavelmente a um fim trágico e, ao mesmo tempo, obsceno, no sentido pleno do

2 Tais linhas reproduzem as correspondentes na versão original (Lord Auch, 1928), que pude consultar na reserva de livros raros da Bibliothèque Nationale (Res. m. Y ${ }^{2}$. 1004), compondo aí um dos inúmeros volumes da chamada coleção do Inferno, que reúne os títulos considerados licenciosos (ver Quignard, 2007a). Há uma tradução para o português realizada por Eliane Robert Moraes (Bataille, 2003:68-69), da qual me vali em alguns trechos, pautada porém na segunda edição, chamada "edição de Sevilha", impressa em Paris, em 1947, por K éditeur; sobre as várias edições de História do olho, ver Surya (2007:388-389). Tanto a versão original como a edição de Sevilha encontram-se no primeiro volume das obras completas de Bataille (1970a; 1970b). Na segunda versão, o excerto citado encontra-se na p. 596. 
termo. Neste percurso, observaria muitos anos depois o escritor $e$ antropólogo francês Michel Leiris, rompem-se "todas as divisórias entre coisas baixas e coisas elevadas" (2004:43), franqueando o intercâmbio insólito entre objetos que, de outra forma, não poderiam se equivaler.

O episódio da morte de Granero é a única passagem verídica, a única "história verdadeira", segundo Leiris (2004:37),de História do olho, isto é, comprometida em descrever fidedignamente, com exceção do que se passa na arquibancada, um acontecimento real. Outros trechos do livro valeram-se igualmente de situações da vivência do autor, porém elas serviram-lhe como pontos de partida, não como objetos de imitação. De fato, em 7 de maio de 1922, quando contava vinte anos e era considerado o sucessor do então recém-falecido Joselito, um dos matadores de maior prestígio da história tauromáquica, Granero foi ferido fatalmente pelo touro Pocapena, o segundo que enfrentava nessa tarde em Madri, na coxa e depois no olho direito (Mandel, 2002:193). O excerto citado acomoda-se assim entre dois planos de realidade, um externo e outro interno: de um lado, a morte de Granero, que lhe serve de fonte; de outro, a intercalação entre a desgraça do matador $e$ a devassidão de Simone, produzida pelo enquadramento obsceno de uma situação trágica.

A possibilidade de atribuir um caráter trágico a uma cena tão vulgar é decorrente do processo de longuíssima duração no qual a tradição judaico-cristã subverteu em todos os sentidos a tradição clássica; esta se orientava por uma hierarquia estilística que confinava os elementos grotescos à comédia, de modo que a aproximação entre os dois planos no trecho acima seria inconcebível. A paixão de Cristo, unindo o mais alto ao mais baixo e instaurando um movimento histórico universal, assinalou um passo decisivo desse processo, que culminou no realismo moderno: daí em diante, a rotina enfadonha de uma pequenaburguesa provinciana como madame Bovary pôde assumir um caráter verdadeiramente trágico. Esse é o argumento apresentado 
em Mimesis, de 1946, pelo filólogo Erich Auerbach (2003) ${ }^{3}$, livro que coroou sua carreira, já em curso nos anos em que História do olho circulava pela primeira vez no circuito de vanguarda parisiense. Tal novela fornece inequivocamente um conjunto rico de questóes sobre a sexualidade e, particularmente, sobre a relação entre a sexualidade e a morte $e^{4}$. No entanto, a sexualidade encontra-se aí vinculada, através de uma interpretação psicanalítica elaborada por seu próprio autor, a uma noção específica de historicidade; esse vínculo permanece até agora ignorado e o argumento contemporâneo de Auerbach permite trazê-lo à tona. Em suma, a inovação literária decisiva do entreguerras consistiu em estabelecer uma mediação subjetiva do real. Assim, a apreensão do real, que Auerbach associa ao movimento histórico, capaz de romper a hierarquia estilística, produzindo assim o realismo, passa aí por uma formulação subjetiva. À primeira vista, História do olho parece furtar-se completamente ao realismo e à historicidade; todavia, uma leitura atenta permite mostrar que a mediação subjetiva, assumindo a forma de uma interpretação psicanalítica, estabelece uma relação entre a morte de Granero e uma força histórica poderosa: a Primeira Guerra Mundial. Nesse sentido, o elemento saliente do excerto é o termo "irrealidade", empregado como produto do entorpecimento dos sentidos: "uma irrealidade bem conforme ao nosso mal-estar". Há um descompasso entre tal sentimento e a descrição objetiva do infortúnio do matador, sincronizada com o vertiginoso desejo de Simone. Para compreender seu significado profundo, é preciso considerar o processo de redação da novela, seguindo um percurso sinuoso que permitirá reencontrar Auerbach mais adiante.

\footnotetext{
3 Para uma introdução didática a Mimesis, ver Waizbort (2013).

4 Vale a pena assinalar a importância e a persistência dessa relação ao longo de toda a obra de Bataille; note-se, por exemplo, que em L'Érotisme, um de seus textos mais importantes, publicado em 1957, poucos anos antes de seu falecimento, o percurso de sua reflexão sobre o erotismo passa pela guerra e pelo sacrifício, entre outros tópicos (Bataille, 1987), dois temas decisivos em História do olho.
} 
2.

Hoje sabe-se que por trás do pseudônimo Lord Auch ocultava-se o escritor francês Georges Bataille, que nunca reivindicou a autoria do livro. No momento de seu lançamento, apenas seus amigos mais próximos sabiam que ela lhe cabia (Armel, 1997:267) ${ }^{5}$. Anos mais tarde, em um artigo dedicado a Por quem os sinos dobram, novela do escritor americano Ernest Hemingway (1944) sobre a Guerra Civil Espanhola, publicado na coletânea que organizou a favor da Espanha republicana derrotada, Bataille diria, sem fazer qualquer menção à História do olho, que estava presente na praça de touros madrilena na tarde fatídica de Granero: "eu estava no lado oposto da arena e, de toda a cena, tomei conhecimento dos detalhes nos relatos - ou nas fotografias - publicados" (Bataille, 1946:120). Nos dias seguintes, a notícia $e$ as imagens do acidente circularam amplamente pela imprensa espanhola genérica e especializada, que lamentou a morte do toureiro ${ }^{6}$. Uma fotografia em particular, flagrando o início do desastre, momento em que o corpo de Granero é arremessado por Pocapena, ganhou destaque e talvez Bataille a viu, ou a reviu, na página da revista madrilena Mundo gráfico, publicada três dias depois, na qual é acompanhada por outras duas: na primeira, o matador encontra-se acuado contra a barrera, a cerca de madeira que delimita o espaço do toureio; na segunda, ele é levado à enfermaria (fig. 1). Nenhuma das imagens publicadas pela imprensa mostra a perfuração do olho pelo chifre, mas algumas retratam o cadáver desfigurado.

5 A primeira edição sob a autoria explícita de Bataille seria lançada apenas postumamente, em 1967, por Jean-Jacques Pauvert, e sem ilustrações (Bataille, 1970a:611).

6 Ver por exemplo, entre muitos outros, os exemplares dos seguintes periódicos publicados em 8 de maio de 1922: La Correspondencia de España, ano LXXV, $\mathrm{n}^{\circ}$ 23.281, pp. 1, 6; El Heraldo de Madrid, ano XXXII, n 11.333, pp. 1-4; El Globo, ano LXVIII, n 15.846 , p. 2; El Toreo, ano XLIX, n 2.760, pp. 1-3. Tais periódicos foram consultados em diversos momentos na Hemeroteca Digital da Biblioteca Nacional de España (http://www.bne.es/es/Catalogos/HemerotecaDigital/). 
No mesmo artigo, Bataille afirma que, após ter testemunhado o acidente, a angústia despertava cada vez que ele ia a uma tourada, sem contudo atenuar seu desejo pelo espetáculo; pelo contrário: tal sentimento exasperava sua vontade. "Comecei a compreender então", explica, "que o malestar é frequentemente o segredo dos maiores prazeres"; mais adiante, ele afirma ter reconhecido,

após alguns meses de estadia na Espanha, que eu estava em um outro mundo moral, menos descontraído e menos amavelmente real, mas, por um lado, bem mais atraente (Bataille, 1946:120).

Além desse artigo, publicado dezoito anos depois de História do olho, e vinte e quatro após a morte de Granero, o único documento sobre o período espanhol de Bataille consiste na correspondência contemporânea trocada com sua prima MarieLouise, na qual ele não demonstra um interesse avivado pelo país. Tal fonte revela na verdade uma postura contemplativa, desejosa de conhecer o Oriente, voltada à meditação, à reflexão sobre os sonhos e à escrita de um romance segundo o estilo de Proust, gostos pessoais que o tornariam predisposto ao projeto surrealista, que nesse momento ainda não existia e do qual ele participaria mais tarde à distância (Bataille, 1997:26-31; Surya, 1992:56). As cartas não mencionam nenhuma palavra sobre a corrida funesta $e$, quando acusam um interesse pela Espanha, este se manifesta na forma religiosa, alimentada pelo catolicismo ao qual ele se convertera durante a Primeira Guerra. Assim, ele compara o brilho do sol, por exemplo, a "um ostensório de estilo barroco" (Bataille, 1997:31; Surya, 1992:59).

A presença de Bataille em Madri, de fevereiro a junho de 1922, justifica-se por sua nomeação como arquivista-paleógrafo na École des chartes, por ocasião da defesa de sua tese, dedicada a um poema medieval. Ele foi o segundo de sua promoção, o que lhe rendeu um estágio na École des Hautes Études Hispaniques de Madri, hoje chamada Casa de Velázquez, criada no início do 
cadernos pagu (58), 2020:e205805

Olhos e colhões: Da sexualidade à historicidade em História do olho

século $\mathrm{xx}$ para acolher estudantes e pesquisadores franceses (Surya, 1992:56) ${ }^{7}$.

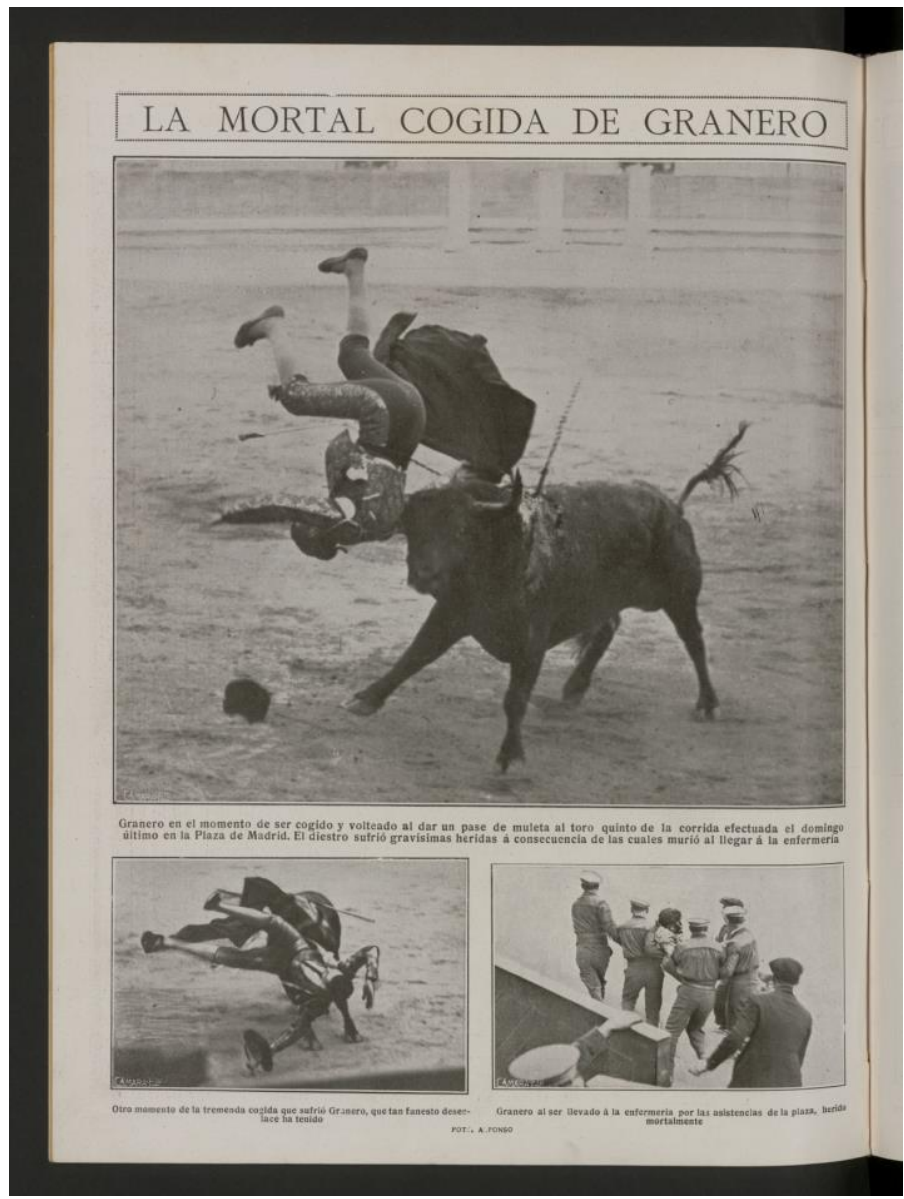

Figura 1. "La mortal cogida de Granero", Mundo gráfico, ano XII, nº 549, 10 de maio de 1922, p. 12. () Hemeroteca Digital, Biblioteca Nacional de España.

7 Cf. Bataille (1970c). Fundada em 1821, a École Nationale des Chartes é um estabelecimento de ensino superior dedicado à formação de conservadores do patrimônio e das bibliotecas; tradicionalmente, o arquivista-paleógrafo promovido em primeiro lugar era enviado à Roma, o segundo, à Madri. 
Durante o estágio, ele foi orientado a pesquisar documentos franceses medievais que se encontravam na Espanha, porém não cumpriu os oito meses obrigatórios na instituição devido à sua nomeação, em junho, como bibliotecário estagiário na Bibliothèque Nationale (Surya, 1992:618; Le Bouler, 1988). Décadas mais tarde, em um artigo que integrou o número da revista Critique consagrado a Bataille, o antropólogo Alfred Métraux, que fora seu colega na École des Chartes e passara um mês na Andaluzia, afirmou que "ele [Bataille] não me pareceu ansioso pelos trabalhos de erudição que serviam de pretexto à sua viagem, mas me impeliu a falar de vestígios árabes e de touradas" (1963:677). Sabe-se, enfim, que durante esses meses ele viajou pela península ibérica, visitando inclusive Sevilha, onde ocorre a derradeira orgia de História do olho.

Pouco se sabe sobre sua temporada além-Pireneus, mas esse pouco contrasta com seu olhar retrospectivo, que procura dar uma coerência excessiva à experiência passada: o entusiasmo declarado pela corrida e pela Espanha no artigo de 1946 não se encaixa com o desânimo relatado à prima em 1922. A interpretação elaborada no artigo, sustentada por dois elementos o mal-estar como fonte do prazer e a sensação de irrealidade -, não apenas se ajusta perfeitamente ao excerto citado de História do olho, como parece explicá-lo a partir de sua vivência espanhola. No entanto, ainda que aquela o ilumine, é justamente o oposto que se passa: a novela proveu o infortúnio do matador de um significado que este é incapaz de produzir por si mesmo, além das circunstâncias nas quais se situam o equívoco técnico que o causou; o olhar retrospectivo de Bataille nada mais fez que fornecer coerência à morte através de critérios que sustentam sua ficção. Em outras palavras, ao olhar para trás em 1946, lembrando-se da tarde funesta de 1922, Bataille se valeu, consciente ou inconscientemente, dos critérios presentes no trecho citado de História do olho, que, redigido em 1927, pautou-se, por sua vez, na memória do mesmo episódio, mediada pela combinação de sua presença na arena com os relatos $e$ as fotografias que lera e vira. Não foi apenas da desastrosa tarde na 
praça de touros madrilena que se alimentou o trecho transcrito; entre ambos, outras experiências se interpuseram.

3.

$\mathrm{Na}$ introdução à tradução brasileira de História do olho, Eliane Robert Moraes observa que:

\begin{abstract}
A objetividade da narrativa contrasta com o caráter insólito e excessivo das fantasias que vão sendo, uma a uma, relatadas, produzindo uma curiosa dialética entre continente e conteúdo. À palavra, prosaica e racional, se justapõe uma substância fantástica, cuja violência poética coloca em risco qualquer tentativa de lucidez. Reside aí, sem dúvida, a originalidade do texto de Bataille, que consegue ser, ao mesmo tempo, um frio documento de observações sexuais e um fabuloso conto de fadas noir (Moraes, 2003:16).
\end{abstract}

O sentimento de irrealidade não é, portanto, um traço exclusivo do excerto. Porém, aí ele contrasta não apenas com a objetividade dominante do livro, mas sobretudo com a descrição objetiva de um episódio real, que, expresso em forma literária, combina a tragédia à obscenidade. Tal sentimento permeia efetivamente toda a obra $e$, desvencilhado da ancoragem fornecida por um evento externo, dá-se curso livre para que ele se manifeste plenamente, em particular nas passagens que buscam vincular os sentimentos dos personagens ao cosmos, beirando o hermetismo (Moraes, 2003:17):

a devassidão que conheço não suja apenas meu corpo $e$ meus pensamentos, mas também tudo o que posso conceber diante dela, isto é, o grande universo estrelado que não desempenha senão um papel decorativo (Bataille, 1970a:45).

A presença constante desse sentimento só é possível porque a novela orienta-se exclusivamente pelo desejo, mostrando-se 
indiferente a qualquer tipo de constrição, inclusive àquelas relacionadas à linguagem, princípio que produz um efeito marcado de despersonalização. A comparação entre as duas versões da obra indica que essa foi de fato a intenção duradoura do autor, uma vez que a segunda versão sofreu uma depuração, criando "um relato mais objetivo, frio e sobretudo indeterminado", e resultando na substituição da interioridade psicológica pela orgânica, na subordinação da consciência ao corpo, "que, liberto de todas as restrições, se abandona ao regime intensivo da matéria" (Moraes, 2003:19). A tendência automática do comportamento dos personagens, guiada pela força irresistível da fantasia, encontra a sua expressão mais completa no caráter objetivo da linguagem, que contrasta justamente com a sensação de irrealidade provocada pela primazia corpórea. Dessa maneira, a conjugação de elementos opostos não se restringe à função de fio condutor da narrativa: ela fornece à novela sua própria forma expressiva.

$\mathrm{O}$ esforço de justapor elementos habitualmente considerados opostos, ou ao menos incompatíveis, encontra-se também presente em três textos redigidos por Bataille na mesma época de História do olho ${ }^{8}$. Um deles, por exemplo, consiste em uma das definições do verbete "Olho", publicadas em 1929, um ano depois do lançamento da novela, no dicionário da revista Documents, que ele próprio dirigia ${ }^{9}$. A contribuição de Bataille intitula-se "Guloseima canibal", segundo a célebre expressão do escritor escocês Robert Louis Stevenson (1900:192). "Sabe-se que o homem civilizado", escreve Bataille (1929), "caracteriza-se pela acuidade de horrores frequentemente pouco explicáveis", entre os quais se encontra o terror suscitado pelos olhos. Ainda que se trate de um sentimento inesperado, uma vez que os olhos parecem, tanto nos homens como nos animais, indissociáveis da

\footnotetext{
8 Cf. Bataille (1929; 1970d; 1970e).

${ }^{9}$ As demais definições foram assinadas pelo poeta Robert Desnos e pelo antropólogo Marcel Griaule. Sobre o dicionário de Documents, ver Richardson (2006) e Zorzi (2013).
} 
sedução, "a sedução extrema está provavelmente no limite do horror". A partir daí, ele aponta alguns exemplos, entre eles o gume de uma lâmina cortando o olho de uma jovem no curtametragem Um cão andaluz, de Luis Buñuel ${ }^{10}$. O caráter insólito do olho ampara-se, portanto, na instabilidade entre o fascínio e a repulsa.

Em um artigo dedicado à História do olho, publicado em 1967 na edição da revista L'Arc preparada em homenagem a Bataille, que falecera cinco anos antes, Leiris explica que, tanto na novela como nos textos escritos em torno dela,

termos habitualmente concebidos como opostos aparecem em conjunção: o terrível e o risível, o resplandecente e o repugnante, o pesado e o leve, o benéfico e o nefasto. Coincidência de contrários, uma das linhas de força do pensamento de Bataille (2004:42).

O pleno desenvolvimento desse pensamento, continua ele, só ocorreria mais tarde, quando Bataille entrou em contato com a filosofia de Nietzsche e com as ideias de Marcel Mauss sobre a ambiguidade do sagrado e o desperdício como instrumento de soberania ${ }^{11}$. "Por enquanto", afirma Leiris,

filósofo em estado selvagem, ele procede, mais que a uma tabula rasa ordenada por razões de método, a um saque alegre tanto dos imperativos morais como dos caminhos traçados por uma lógica prudente, e ele parece lançar desordenadamente sobre o papel todos os motivos sensíveis que são o suporte ou o reflexo de suas obsessões, estoque de temas retomados ulteriormente e refinados ou enriquecidos, mas aqui ainda mais pungentes por se separarem dificilmente do caos (Leiris, 2004:42).

${ }^{10}$ Un chien andalou, produzido e dirigido por Luis Buñuel, 1929, 16 min.

${ }^{11}$ Ver os textos de Bataille reunidos em Hollier (1995) e também Goyatá (2016). 
Nessa "espécie de aterrador Triunfo do Olho", como denomina Leiris (2004:44) o efeito provocado pelos textos de Bataille, a relação entre os elementos se estabelecem "em função menos de um simbolismo geral do que de associações pessoais", criando um "universo transformado em dicionário onde se esvai o sentido das palavras, pois todas se definem umas pelas outras", um "universo tão pouco hierarquizado que tudo aí é intercambiável" (2004:43). Compreende-se então o estado completamente desbaratado no qual se encontra o leitor de Bataille diante da novela e dos textos dedicados ao tema do olho, nos quais cada passo é dado segundo combinações puramente arbitrárias, difíceis de penetrar, exigindo uma leitura rigorosamente submissa à cadeia de significados daí decorrente. Leiris questiona se não se trataria afinal da

\begin{abstract}
materialização de um tipo de colagem surrealista ou de sobreimpressão permitida pela câmera, imagem de carne e osso na qual, tão perturbadores como os jogos de palavras sobre os quais repousam os trocadilhos poéticos, interviriam jogos de coisas e, excepcionalmente, jogos de partes do corpo? $(2004: 44)^{12}$.
\end{abstract}

O procedimento de colagem visa produzir novos significados, geralmente inquietantes, porque são organizados pelo capricho, a partir da aproximação de elementos inusitados preexistentes. Dessa maneira, integra-se o real ao texto, não como reflexo de algo exterior, mas em função da vontade criadora, que conduz assim a um efeito de real. Seguindo essa interpretação, a perfuração do olho de Granero pelo chifre não tem sentido em si mesma, mas apenas na relação simultânea $e$ paralela com a penetração da vagina de Simone pelo colhão; justapostos dessa forma, a morte e o prazer, o infortúnio e a volúpia, a tragédia e a obscenidade, coincidem sem nunca se combinarem permanentemente.

${ }^{12}$ Sobre a fragmentação da figura humana e o intercâmbio desses fragmentos, ver Moraes (2012). 
4.

O vislumbre retrospectivo, da parte de Leiris, de um procedimento surrealista em História do olho não se pautava exclusivamente em uma leitura interna da novela. Leiris e Bataille se conheceram - segundo um manuscrito memorialístico deste, redigido em 1951, sem intenção de ser publicado (2004b:51-52, 70, nota 2) - no final de 1924, por intermédio de Jacques Lavaud, amigo de liceu de Leiris, e então colega de Bataille na Bibliothèque Nationale. Logo depois, a adesão de Leiris ao surrealismo, que dava seus primeiros passos, adiou o pleno comprometimento à recém iniciada amizade, irritando Bataille, que se sentia em segundo plano e não se interessava "por nada que não fosse desarticulado e inconsequente" (2004b:54). Desde o princípio, Bataille manteve uma posição desconfiada frente ao movimento: ele considerava o manifesto surrealista "ilegível" $e$ julgava "enfadonha" a escrita automática, "o método ao qual [André] Breton reduzia a literatura" (2004b:55). Segundo seu biógrafo, essa desconfiança não implicava em uma postura inicial declaradamente hostil, como o próprio Bataille deixava supor; ao contrário, considerando o prestígio de Breton, a sedução de Louis Aragon e a capacidade de atração do movimento, além do fato de que Bataille até então não escrevera nada, não é improvável que ele tenha considerado, ainda que não se saiba quão seriamente, tornar-se surrealista. De qualquer forma, essa possibilidade foi-lhe interdita, pois, após um encontro mediado por Leiris, este lhe informou que Breton o julgara mal, descrevendo-o como "um obcecado" (Surya, 1992:104; Bataille, 2004b:62). A única contribuição de Bataille ao movimento consistiu na tradução de algumas fatrasies, poemas deliberadamente incoerentes do século XIII, publicada anonimamente em La Révolution Surréaliste, no

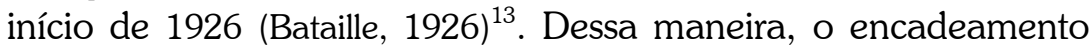
mais provável de eventos consiste em uma desconfiança inicial

${ }^{13}$ De acordo com Leiris, Bataille teria intencionalmente deixado de assinar a sua tradução, tamanha era a sua reticência pelo surrealismo (Surya, 1992:104, nota 1). 
que se transforma, subsequentemente a um flerte mal sucedido, em hostilidade declarada.

Nesses mesmos anos, Bataille dedicava muitas de suas noites à bebida, à jogatina, às prostitutas (Surya, 1992:108). Esses hábitos libertinos representam uma fissura na biografia de alguém que, criado sem educação religiosa - o pai era "um homem sem religião", a mãe, "indiferente" (Bataille, 2003:98; 1971a:61) -, converteu-se ao catolicismo aos dezessete anos e considerou seriamente o monasticismo e o sacerdócio, chegando a frequentar o seminário por quase um ano (Surya, 1992:35-37). Até o final de sua estadia na Espanha, em meados de 1922, ele era certamente um católico praticante, mas no momento em que conheceu Leiris, cerca de dois anos depois, compartilhava a ideia de fundar uma revista literária com sede em um prostíbulo (Bataille, 2004b:53). Não se entende como ocorreu uma guinada tão radical capaz de transformar um jovem descrito há pouco pelos amigos como "meditativo e romântico, dividido entre o gosto da cavalaria $e$ o da religião, de um jeito ou de outro disposto a sentimentos $e$ ambições nobres" (Surya, 1992:108), em um boêmio inveterado. No caminho entre a igreja e o bordel, entre os sentimentos mais elevados e os mais baixos, abre-se uma lacuna produzida pelas fontes, impedindo assim a compreensão exata dessa transição. A postura excessivamente depravada, explica Leiris, somava-se ainda à violência $e$ à obsessão expressas em seus escritos contemporâneos, que não sobreviveram, e até mesmo em um suposto episódio de roleta russa, comportamento que despertou a atenção dos amigos, levando à sugestão de terapia psicanalítica (Surya, 1992:108, 123, 623).

A análise de Bataille foi empreendida pelo psiquiatra Adrien Borel, especialista em toxicomania e um dos fundadores, em 1926, da Sociedade Psicanalítica de Paris, onde ocupava uma posição minoritária, desafeita ao dogmatismo freudiano. Analista de vários escritores do círculo surrealista, entre eles Raymond Queneau, e arisco ao uso excessivo do divã, Borel praticava uma técnica "pouco rigorosa e não prop[unha] um modelo de cura ritualizado", deixando "seu paciente debater-se com as violências 
de seu inconsciente, sobretudo quando se trata de um criador" (Roudinesco, 1994:358). Não se sabe exatamente quando nem como transcorreu a análise de Bataille. Segundo a hipótese de seu biógrafo, ela teria durado um pouco mais de um ano e situaria-se entre a redação de $W .-C$., livro inacabado cujo manuscrito seria destruído, e a conclusão de História do olho ${ }^{14}$ intervalo que se ajusta entre, de um lado, o final de 1925, ocasião de seu primeiro contato com o analista, de outro, 1927, momento em que Borel concluiu sua leitura da novela (Surya, 1992:125). ${ }^{15}$ Supõe-se ainda que a terapia pautou-se no estímulo de Borel para que Bataille escrevesse, produzindo assim as imagens que, a um só tempo, serviriam de chaves interpretativas da análise e dariam forma à novela; a analogia convincente entre os olhos e os colhões por meio da afinidade morfológica, por exemplo, deveu-se ao esclarecimento anatômico do analista, que corrigiu a ideia equivocada de seu paciente, que tomava os testículos taurinos por "vermelho vivo" ao invés do "branco carminado" que, somado ao formato ovoide, assemelha-os aos olhos (Bataille, 1970a:75; Surya, 1992:125). Em uma entrevista concedida em 1961, um pouco antes de falecer, Bataille diria que a análise com Borel "transformou-me do ser completamente doentio que eu era em alguém relativamente viável"; "o primeiro livro que escrevi", acrescenta ele, referindo-se a História do olho sem contudo mencioná-lo explicitamente, "só pude escrevê-lo depois da psicanálise, sim, ao sair dela. E julgo poder dizer que só liberto

\footnotetext{
${ }^{14} \mathrm{~A}$ Bibliothèque Nationale possui um manuscrito intitulado História do olho (Departamento de Manuscritos, NAF 26263), proveniente da biblioteca de Charles de Noailles, colecionador de textos surrealistas e manuscritos de Sade. Trata-se de um manuscrito muito próximo da versão publicada. Ele foi redigido no verso de cento e setenta fichas de empréstimo ao leitor da Bibliothèque Nationale, onde Bataille exercia a função de bibliotecário do gabinete de Medalhas. Estima-se que ele foi escrito entre 1926 e 1927, período no qual uma suposta versão anterior do texto, produzida entre 1920 e 1925, enquanto Bataille distanciava-se do catolicismo, sofreu as modificações provocadas pela análise de Borel (Surya, 2007:388)

15 "Eu escrevera, um ano antes de História do olho, um livro intitulado W.-C." (Bataille, 1971a:59).
} 
dessa maneira pude começar a escrever" (Chapsal, 1986:200). A redação da novela por meio da psicanálise marca, portanto, como escreve Eliane Robert Moraes, "o nascimento de um escritor" (2003:10).

5.

Se o processo de escrita de História do olho tornou Bataille psicologicamente "viável", sua publicação estabeleceu, na chave da sexualidade, uma distância objetiva em relação ao surrealismo ortodoxo. Ainda que não se conheça a opinião de Breton sobre a novela, uma transcrição das discussões surrealistas sobre a sexualidade, publicada no mesmo ano de 1928 em La Révolution Surréaliste (Breton, 1928), permitiu ao biógrafo de Bataille esboçar as diferenças que os separavam nesse quesito (Surya, 1992:134135). Entre elas, destaco duas: primeiro, o exclusivismo pelo qual Breton concebia o amor, única fonte possível de erotismo, implicava na interdição absoluta de qualquer elemento terciário à relação amorosa, enquanto em História do olho Bataille convoca, para a realização das fantasias do narrador e de Simone, o voyeurismo de sir Edmond e toda a multidão na praça de touros, horrorizada com a morte de Granero; segundo, a exclusão de qualquer espécie de perigo exterior ao amor físico, para Breton, contrasta com o intenso estímulo produzido por tal ameaça para Bataille $^{16}$. Essas opiniões sexuais não eram compartilhadas por todos os surrealistas; a própria ideia de uma discussão sobre a sexualidade pressupõe divergências ${ }^{17}$. Ainda assim, a centralidade

${ }^{16}$ Diante da questão proposta por ele mesmo, e repetida depois por Man Ray, sobre o ménage à trois de um homem com duas mulheres, Breton responde: "Completamente contra"; mais adiante, declara: "Eu não saberia suportar a presença de nenhum terceiro" (Breton, 1928:35, 39). A questão sobre o perigo externo ao ato sexual também foi feita por Breton, que sugere a morte como exemplo de tal ameaça e, por sua vez, responde: "É impensável ter a consciência do perigo exterior no amor físico com uma mulher que se ama" (Breton, 1928:39).

${ }^{17}$ Por exemplo, Pierre Naville afirma que o ménage à trois é "desejável", podendo inclusive constituir um estímulo à relação, e Raymond Queneau 
da posição social de Breton no movimento, somada à postura hostil da maioria dos surrealistas em relação às heterodoxias sexuais, fomentou o embate entre a liberação do desejo, um dos pilares da cartilha surrealista, e a exaltação do amor, oposta a todas as práticas sexuais vistas como pervertidas (Carassou, 1982). Considerando, portanto, a importância, tanto psicológica como social, de História do olho para a iniciante carreira literária de Bataille, os critérios sexuais transgressores que aí fornecem ritmo à narrativa apartavam-no definitivamente do surrealismo oficial, mas certamente não das margens do movimento, de onde proveio o estímulo à publicação da novela ${ }^{18}$.

Em meados dos anos 1920, no mesmo período em que dava seus primeiros passos na carreira literária, Bataille foi convidado pelo pintor André Masson, de quem se tornara rapidamente amigo por intermédio de Leiris, a colaborar em uma coleção erótica (Bataille, 2004b:63; Saphire \& Cramer, 1994:30). Tal coleção foi concebida e dirigida por Masson e pelo poeta e jornalista Pascal Pia; sua publicação cabia a René Bonnel. Este, que transitava nos círculos bibliófilos e trabalhava no mercado livreiro desde antes da guerra, tornou-se, em parceria com Pia, editor de livros clandestinos a partir de 1925. Para se precaver das sanções judiciais, seus títulos eram impressos sem o nome do autor, que se valia frequentemente de um pseudônimo, e sem a especificação

considera-o "completamente desejável e estimável".Sobre a ameaça de morte durante o ato sexual, Jacques Prévert avalia-a como "um estimulante", observando que "as pessoas que não conheceram esse perigo jamais fizeram amor" (Breton, 1928:35, 39).

${ }^{18}$ É preciso observar que, a despeito da centralidade indiscutível de alguns de seus membros, sobretudo Breton e Aragon, o grupo surrealista era numeroso e sua composição variou bastante ao longo do tempo; basta citar a célebre dissidência do final dos anos 1920, dirigida especialmente contra a postura autoritária de Breton e endossada não apenas por Leiris como também por André Masson, que ilustrou História do olho (ver infra). Dessa forma, é impossivel, e certamente equivocado, definir de maneira circunscrita o que os surrealistas entendiam por sexualidade, que se configurava na verdade como um objeto de disputa, como bem mostram os exemplos citados. Sobre a história do movimento, ver particularmente Durozoi (2004). 
do local e da data de publicação, ou com tais informações apócrifas (Marchand, 2000; Brécourt-Villars, 2001; Quignard, 2007b:355), daí o anonimato da novela de Bataille, atribuída ao desconhecido Lord Auch. Essas medidas eram necessárias devido à censura, que, apesar de ser mais tolerante na França do que na Inglaterra e nos Estados Unidos, tinha o amparo legal e o apoio da Igreja e de grupos privados para defender a "decência pública" (Phillips, 2005:128). As audácias literárias, incluindo a ficção erótica, encontraram terreno fértil em Paris, mas isso não significava que não houvesse limites nem resistências. História do olho foi o segundo título da coleção, precedido por Le Con d'Irène, de Louis Aragon (1928), ilustrado por Masson. De acordo com este, Bataille pediu-lhe que ilustrasse também sua novela, focando-se com precisão em certos detalhes da narrativa (Saphire \& Cramer, 1994:32). Tratava-se de um pedido contrário à tendência da época, pois, além de ser uma publicação erótica, a novela também poderia ter sido um livro de pintor, isto é, um volume luxuoso com gravuras exclusivas, produzidas por um artista interessado na concepção geral que ele próprio tinha da obra, ultrapassando assim os limites estreitos da ilustração. O ano de 1928 é o momento em que esse tipo de edição atinge seu auge na França, $e$ não se sabe por que Bataille e Masson fizeram uma escolha convencional (Coron, 1991:462, nota 63) ${ }^{19}$. De qualquer forma, entre as oito litografias produzidas pelo pintor, nenhuma se detém sobre a coincidência entre o infortúnio de Granero e o prazer de Simone $e^{20}$. Neste momento, a tourada provavelmente

\footnotetext{
${ }^{19}$ Chapon (1987:48-50) defende que a classificação "livro de pintor" não é adequada porque repousa sobre um desequilibrio, excluindo a integralidade da obra ao privilegiar o trabalho do pintor sobre o do escritor; ele propõe em seu lugar a expressão "livro ilustrado". Daniel-Henry Kahnweiler, marchand de Masson, reprovou-lhe a concepção ilustrativa de suas gravuras para História do olho (Surya, 2007:388). Por sua vez, Leiris diria décadas depois que tais ilustrações seguiram "um estilo menos verista que lírico" (2004:35).

${ }^{20}$ Além da primeira edição de História do olho, livro de difícil acesso devido à sua raridade, as ilustrações de Masson encontram-se na edição fac-similar de Jean-Jacques Pauvert (Bataille, 2001), que também inclui a edição de Sevilha.
} 
ainda não o fascinava ou, ao menos, não o suficiente para que ele escolhesse desenhá-la entre todas as cenas da novela; Masson, contudo, produziu inúmeros quadros e desenhos sobre o tema durante sua temporada na Espanha, na metade da década de $1930^{21}$.

6.

O erotismo da novela é produzido pela expressão dos desejos sexuais levados ao paroxismo, momento em que eles coincidem com a morte; tal recurso remete sem dúvida a Sade, que "explorou a derradeira possibilidade lógica da pornografia: a aniquilação do corpo, o próprio suporte do prazer, em nome do desejo" (Hunt, 1996:35) ${ }^{22}$. Trata-se aí de um traço fundamental de História do olho, até agora somente aludido: seu caráter pornográfico. A estrutura dessa novela pode ser descrita como uma pornotopia, expressão cunhada por Steven Marcus (1974:44 apud Hunt, 1996:39) para se referir à fantasia utópica predominante na pornografia, cuja tendência é arrebatar-lhe a realidade externa ou social, dispondo o espaço e o tempo como medidas exclusivas da série de relações sexuais. Desse modo, a novela se encaixa bem no percurso histórico desse gênero que, inventado no Quinhentos italiano a partir de fontes clássicas, encontra-se profundamente imbricado ao potencial contestatório da cultura impressa. Até a Revolução Francesa, a pornografia encerrava um sentido duplamente político: de um lado, uma vez que, segundo a

Ambas as edições, com suas respectivas ilustrações, foram igualmente reproduzidas na edição Pléiade da obra romanesca de Bataille (2004a:1-107).

${ }^{21}$ Sobre as ilustrações de História do olho, não apenas as realizadas por Masson, mas as produzidas subsequentemente por outros artistas, que também não contemplaram o episódio da morte de Granero, ver Teixeira (2011). A respeito da temporada de Masson na Espanha, ver especialmente Masson (1993).

${ }^{22}$ Leiris observou que a ficção de História do olho, "como as mais notórias daquelas que Sade imaginou, participa do gênero noir tanto quanto do gênero erótico e ilustra em traços de fogo uma filosofia, explícita em Sade (que confia a vários de seus personagens o cuidado de expor suas ideias), mas ainda implícita nesse primeiro livro de Georges Bataille" (2004:33). 
concepção iluminista de natureza, o desejo sexual era visto como natural, ele trazia consigo efeitos benéficos, não havendo portanto sentido em reprimi-lo; de outro, conforme a crise social alastravase pela Europa setecentista, a sátira política presente nesse gênero desde sua origem se acirrava, atacando o clero, a corte e o próprio rei. O século XIX testemunhou a emergência plena da pornografia como um gênero próprio de representação, apartando-se da classificação "livro filosófico" em uso durante o Antigo Regime ${ }^{23}$. Ela não poderia ter alcançado tal estatuto em outro momento senão quando o potencial da imprensa realizou-se plenamente, disseminando palavras e imagens entre a massa; todavia, tratou-se sobretudo de um estatuto pejorativo, julgado imoral da perspectiva social $e$ não mais do ponto de vista estritamente político, porque o próprio gênero abandonou seu caráter sedicioso, dedicando-se exclusivamente a excitar sexualmente seus leitores. Em contrapartida, se tal gênero renunciou ao radicalismo político propriamente dito, ele permaneceu politicamente contestatório no âmbito moral: "Se todos os corpos fossem intercambiáveis - um tropo dominante na pornografia -, então as diferenças sociais $e$ de gênero (e talvez até raciais) perderiam efetivamente seus significados" (Hunt, 1996:44) ${ }^{24}$.

No episódio da morte de Granero, trata-se particularmente, como diz Leiris, de um intercâmbio entre partes de corpos: olhos $e$ colhões. O infortúnio do matador adquire seu significado

\footnotetext{
${ }^{23}$ Uma análise dos usos políticos da pornografia, ainda indistinguível dos sediciosos "livros filosóficos", às vésperas da Revolução Francesa, encontra-se em Darnton (1996).

${ }^{24}$ Como já foi assinalado nesta mesma revista (Gregori \& Días-Benítez, 2012), a categoria pornografia possui uma multiplicidade de sentidos em disputa, incluindo juízos de ordem moral com um vocabulário recorrente (vulgar, obsceno, baixo). Neste artigo, tal vocabulário não encerra um juízo desse tipo, ; seu emprego remete, na verdade, à transformação do sistema classificatório literário, ou seja, a possibilidade de tratar de forma séria, e mesmo trágica, um assunto que antes jamais se prestaria a tanto. Em contrapartida, é tão revelador que Bataille tenha publicado anonimamente História do olho em uma coleção dita erótica, como o fato da Bibliothèque Nationale manter seu exemplar original da novela na coleção do Inferno.
} 
exclusivamente em função do desejo de Simone; apartado deste, não haveria motivo para sua presença. $\mathrm{E}$ uma vez que a fantasia pura expulsa os constrangimentos sociais, não há nenhuma consequência para a escalada de excessos da dupla protagonista, cuja única fonte de tribulação consiste na vontade incontrolável de satisfazer os próprios desejos. Até mesmo a partida à Espanha, empreendida para escapar dos possíveis problemas decorrentes do suicídio de sua companheira de orgias, consiste muito menos em um imperativo do que em um pretexto para intensificar as aventuras sexuais, que alcançam seu ápice justamente alémPireneus. Assim fazendo, Bataille vale-se da imagem de uma Espanha erótica e violenta, povoada por figuras exóticas, entre eles os toureiros e os bandidos tão estimados pela literatura romântica. História do olho não se distingue, portanto, dos demais textos literários dedicados à corrida de touros que foram produzidos na Paris entreguerras por outros escritores, entre eles Leiris e Hemingway. Tais escritores foram os primeiros fora da Espanha que não apenas procuraram entender seriamente a tourada, vista tradicionalmente pelos viajantes estrangeiros como uma atividade grotesca, como se esforçaram em elevá-la à categoria trágica. No entanto, a despeito de tal esforço, o interesse desses literatos era suscitado pelo contraste que a corrida, e a Espanha em geral, apresentavam diante das agruras da modernidade, sobretudo aquelas acarretadas pela guerra. Traçando assim uma fronteira sobre os Pireneus, atribuía-se um caráter inegavelmente exótico a toda a península ibérica (Sobral, 2015).

7.

A princípio, tudo levaria a crer que História do olho é completamente alheia a tudo que não se submeta à vontade inflexível da fantasia; tal conclusão é, contudo, apenas parcialmente verdadeira. A novela encontra-se dividida em duas partes: na primeira, intitulada "Narrativa", desenrola-se a sequência de ousadias pornográficas, inclusive o deleite de Simone com o colhão taurino; na segunda, nomeada 
"Coincidências", a voz do autor volta-se para uma reflexão sobre a própria narrativa. Nessa segunda parte, ele afirma que foi levado a redigir sua narrativa, "em parte imaginária", pela vontade de se afastar provisoriamente de si mesmo; "eu acreditava assim, no começo", explica, "que o personagem que fala em primeira pessoa não tinha nenhuma relação comigo". Algumas coincidências fizeram com que ele revisse tal pressuposto, à medida em que elas acusavam "indiretamente o sentido do que escrevi" (Bataille, 1970a:73). Entre elas, encontra-se o vínculo entre, de um lado, o olho do padre sevilhano descravado pela orgia feroz que encerra a novela, de outro, o olho de Granero cravado pelo chifre do touro. O autor só se deu conta da afinidade entre esses dois olhos após ter imaginado o primeiro episódio, que o remeteu à "trágica corrida de touros à qual assisti realmente" (Bataille, 1970a:74), levando-o a inseri-la na novela; ele continua:

A abertura do olho do padre não era, como eu acreditava,
uma invenção gratuita, era somente a transposição sobre
uma outra pessoa de uma imagem que guardara sem
dúvida uma vida muito profunda. Se eu inventara que se
arrancava o olho do padre morto, é porque eu vira um
chifre de touro arrancar o olho de um matador. Assim as
duas imagens precisas que provavelmente mais me
abalaram foram destacadas do mais obscuro de minha
memória - e sob uma forma irreconhecível - desde que me
deixara sonhar obscenidades (Bataille, 1970a:74).

Em seguida, ele conta que "um de meus amigos que é médico", sem dúvida Borel (Surya, 1992:125), valendo-se de um manual de anatomia, corrigiu-lhe a descrição dos colhões: ao invés de "vermelho vivo", eles são semelhantes, tanto na forma como na cor, ao globo ocular. "Desta vez", prossegue,

arrisquei explicar relações tão extraordinárias supondo uma região profunda de meu espírito onde coincidiam imagens elementares, todas obscenas, as quais desliza 
indefinidamente a consciência, incapaz de suportá-las sem estilhaço, sem aberração (Bataille, 1970a:75, grifo do autor).

"Coincidências" foi escrito durante a análise com Borel (Surya, 2007:388); não é surpreendente então encontrar aí tal explicação psicanalítica: trata-se do mecanismo de deslocamento empregado defensivamente pelo inconsciente no intuito de desviar a atenção da consciência de um objeto com alto valor psíquico, e portanto intolerável para outro com baixo valor psíquico, resultando em uma desfiguração do objeto censurado (Freud, 2019:350).

Através desse procedimento indiciário, forma de conhecimento indireta por excelência (Ginzburg, 2002), Bataille deu-se conta do vínculo profundo que une, em sua subjetividade, olhos e colhões. Ao contrário do que ele pensara, a distância que o separava da voz narrativa da novela é muito menor, uma vez que ela se alimenta dos conteúdos interditos de sua psique e, assim, de sua própria vida. Como escreveria Leiris, "o 'eu' suposto do narrador duplica-se abertamente em um 'eu' real" (2004:34). Em contrapartida, essa aproximação subjetiva tem por efeito produzir um distanciamento em relação à narrativa (Surya, 1992:126); isso porque, uma vez reveladas as chaves interpretativas pelo próprio autor, atenua-se a força fantasiosa do texto em benefício de um significado antes ausente, de forma que o leitor jamais poderá relê-lo com os mesmo olhos, tampouco desconsiderá-las, mesmo que queira vasculhar aí outros sentidos. No entanto, as relações descobertas entre esses elementos - o olho arrancado do padre sevilhano, o olho perfurado de Granero, os colhões taurinos - não esgotam a cadeia de associações subjetivas de Bataille; em outras palavras, ele não chegou ainda ao objeto censurado por seu inconsciente.

8.

Continuando sua investigação, outras lembranças ainda mais pessoais vêm à tona, desta vez relacionadas com seu pai: 
Nasci de um pai tabético, que me concebeu já cego e que pouco depois de meu nascimento foi confinado à sua poltrona por sua sinistra doença. Ao contrário, contudo, da maior parte dos meninos que se apaixonam por suas mães, fui apaixonado por esse pai. Ora, sua paralisia e sua cegueira estavam ligados ao fato seguinte. Ele não podia como todo mundo urinar nos water-closets, mas era obrigado a fazê-lo sobre sua poltrona dentro de um pequeno receptáculo e, como isso ocorria frequentemente, ele não se incomodava de fazê-lo diante de mim sob uma coberta que, sendo cego, dispunha em geral de forma errada. Mas o mais estranho era certamente sua maneira de olhar enquanto mijava. Como ele não via nada, sua pupila subia quase sempre para o vazio, sob a pálpebra, $e$ isso ocorria em particular nos momentos em que mijava. Ele tinha, ademais, olhos muito grandes sempre muito abertos em um rosto em forma de bico de águia, e esses grandes olhos eram, portanto, quase inteiramente brancos quando ele mijava, com uma expressão completamente estultificante de abandono e desvario em um mundo que apenas ele podia ver e que lhe dava um vago riso sardônico $e$ ausente (eu bem gostaria aqui de lembrar tudo ao mesmo tempo, por exemplo o caráter errático do riso isolado de um cego, etc., etc.). Em todo caso, é a imagem desses olhos brancos naquele momento que está diretamente ligado, para mim, àquela dos ovos e que explica a aparição quase regular da urina cada vez que aparecem olhos ou ovos na narrativa (Bataille, 1970a:75, grifos do autor).

A paralisia e a cegueira de Joseph-Aristide Bataille, encerrando-o repetidamente em um "estado de sujeira e fedor", eram decorrentes da sífilis, que, em seu estágio mais avançado, trouxe também a demência; esta chegou quando "minha afeição por meu pai transformou-se em ódio profundo e inconsciente", capaz de fazê-lo desfrutar dos gritos de dor do enfermo. Após o primeiro episódio de insanidade, "discursos veementes que o sifilítico gritava literalmente em seu quarto", o médico foi chamado; no momento em que ele se retirou ao quarto adjacente 
para conversar em particular com a esposa do doente, este lhe gritou diante do filho, que contava então quatorze anos: "Doutor, avise-me quando acabar de foder minha mulher!" (Bataille, 1970a:77, grifo do autor). Além de destruir instantaneamente, como Bataille diz, sua educação severa, essa frase impôs-lhe

\begin{abstract}
uma espécie de obrigação constante, até aqui submetida inconscientemente $e$ indesejada: a necessidade de encontrar continuamente seu equivalente em todas as situações em que me encontro e é isso que explica em grande parte História do olho (Bataille, 1970a:77).
\end{abstract}

Essa situação desgraçada provocaria ainda outro infortúnio: pouco depois do acesso de loucura de seu pai, Bataille testemunhou uma "cena ignóbil", provavelmente relacionada à doença paterna, à qual sua avó materna expôs sua mãe, MarieAntoinette, que adentrou subsequentemente em um quadro depressivo severo, tentando o suicídio duas vezes sem sucesso (Bataille, 1970a:77).

9.

Tendo alcançado o fim da cadeia de associações psíquicas, no qual se encontra a figura horrenda do pai - definhado, cego, desvairado -, a investigação estaria aparentemente concluída, se não fosse por Le Petit, opúsculo erótico que Bataille publicou clandestinamente sob o pseudônimo Louis Trente, em 1943. Entre os cinco capítulos do livreto, o leitor encontra no terceiro o título "W.-C. Prefácio à História do olho"; nele, o autor explica que, um ano antes de ter redigido a novela, escreveu um livro denominado $W$.-C., cujo manuscrito acabou por destruir ${ }^{25}$. Em contrapartida, ele se diz "contente com a alegria fulminante do olho" (Bataille,

\footnotetext{
${ }^{25}$ De acordo com Leiris (Surya, 1992:112), o único trecho sobrevivente de W.-C. deu origem, sem que se saiba o quanto dele foi reescrito, ao primeiro capítulo de Le Bleu du ciel (Bataille, 1957). Le Bleu du ciel foi escrito em 1935, com exceção do capítulo que lhe fornece seu título, redigido no ano anterior, durante uma visita ao pintor André Masson, que então vivia na Espanha (Bataille, 1971b:560).
} 
2003:95, grifo do autor), o que sugere os efeitos benéficos da análise com Borel. Nesse capítulo, Bataille faz duas revelações importantes. Primeiro, ele explica o significado do pseudônimo Lord Auch:

o nome de Lord Auch faz referência ao hábito de um dos meus amigos: quando irritado, em vez de dizer "aux chiottes!' [à latrina], ele abreviava dizendo "aux ch". Em inglês, Lord significa Deus (nas Escrituras): Lord Auch é Deus se aliviando (Bataille, 2003:96, colchetes da tr.).

Segundo, ele confessa:

Como meu pai me concebeu cego (completamente cego), eu não posso arrancar meus olhos como Édipo.

Como Édipo, decifrei o enigma: ninguém o decifrou mais profundamente do que eu.

No dia 6 de novembro de 1915, numa cidade bombardeada, a quatro ou cinco quilômetros das linhas alemãs, meu pai morreu em estado de abandono.

Minha mãe e eu o abandonamos, durante o avanço alemão, em agosto de 1914.

Nós o deixamos com a empregada.

Os alemães ocuparam a cidade, depois a evacuaram. Só então foi possível retornar: minha mãe, incapaz de suportar tal ideia, acabou enlouquecendo. Por volta do final do ano, minha mãe se recuperou: ela não me deixava voltar para $\mathrm{n}$. Raramente recebíamos cartas do meu pai, ele mal dava conta de seu desvario. Quando soubemos de sua morte, minha mãe aceitou ir comigo. Ele morreu poucos dias antes da nossa chegada, perguntando por seus filhos: nós encontramos um caixão velado no quarto (Bataille, 2003:97).

"N" quer dizer Reims, cidade distante cento e cinquenta quilômetros a nordeste de Paris e localizada entre a capital e o avanço das tropas alemãs. Nos primeiros dias de agosto de 1914, após declarar guerra à França, a Alemanha invadiu a Bélgica, que se recusara a autorizar a passagem do exército alemão devido à 
posição neutra que assumira diante do conflito. A despeito da resistência belga, os alemães atravessaram seu território em direção à fronteira francesa, invadida subsequentemente com sucesso. Mesmo auxiliados pelos britânicos, os franceses foram incapazes de repelir a ofensiva alemã, que alcançou o rio Marne (Surya, 1992:29; Audoin-Rouzeau \& Becker, 2013:4). Os invasores cometeram, porém, um erro: tomaram a retirada francesa por uma debandada e concluíram que deveriam prosseguir até Paris sem conceder tempo para uma reorganização. Tal movimento deixou um dos flancos alemães vulnerável, permitindo a contraofensiva francesa, empreendida com o objetivo categórico de impedir o avanço inimigo, mesmo que isso significasse morrer para manter a posição; a estratégia funcionou e os alemães foram obrigados a recuarem, marcando um dos últimos deslocamentos de tropas no fronte ocidental antes do estabelecimento das trincheiras (Krumeich \& Audoin-Rouzeau, 2013:284). Tal episódio, que ficaria conhecido como a batalha do Marne, terminou em 9 de setembro; quatro dias antes, apesar de declarada cidade aberta, Reims foi bombardeada, pilhada e quase completamente destruída. Nesse momento, Bataille e a mãe já haviam sido evacuados, junto com o restante da população civil, refugiando-se na casa dos avós maternos, em Riom-ès-Montagnes, na Auvergne, cerca de seiscentos quilômetros ao sul; o pai permaneceu na cidade condenada, sem que se conheçam os detalhes dessa separação (Surya, 1992:29, 35). A linha de trincheiras acabou estabelecida além de Reims, de modo que, no final de 1915, mãe $e$ filho puderam finalmente retornar, apenas para encontrar um caixão fechado. O biógrafo de Bataille escreve com razão a respeito do pai: "O destino não fora apenas dramático, fazendo dele um enfermo e um louco; era necessário ainda que fosse trágico" (Surya, 1992:30).

Agosto de 1914 apresenta-se então como uma data crucial na vida de Bataille, marcada não apenas por essa perda irreparável, como pela conversão religiosa. A condição sublime almejada pela humildade da piedade cristã seria depois substituída pela degradação mais baixa da libertinagem, sem que se saiba 
qual mediação franqueou tal guinada; talvez ela resida na necessidade de conforto que a religião não lhe foi capaz de fornecer: "Minha devoção nada mais é que uma tentativa de fuga: queria escapar do destino a qualquer preço, eu abandonei meu pai" (Bataille, 2003:98). A redação de um prefácio à História do olho, função atribuída ao capítulo intitulado $W$.-C., sem dúvida uma referência aos water-closets interditos ao pai e mencionados em "Coincidências", não deixa de ser inusitada porque, ao revelar mais uma chave interpretativa da novela - os efeitos trágicos da guerra sobre sua família -, Bataille aumentou ainda mais a distância entre o texto e seus comentários, impedindo, desta vez antes que o leitor inicie a leitura, uma apreensão completa de seu caráter fantasioso ${ }^{26}$. Leiris observou que Bataille, nas edições seguintes de História do olho, além de realizar cortes no texto a fim de torná-lo mais próximo de uma "redação cerrada", renomeou "Coincidências" como "Reminiscências", imprimiu-o em caracteres menores, submeteu-o a um certo abrandamento $e$ excluiu a frase na qual afirma que deu início à escrita sem um objetivo específico, movido apenas pela vontade de se afastar provisoriamente de si mesmo. Assim fazendo, a exegese autobiográfica teria sido rebaixada de segunda parte da narrativa a "simples comentário"; ela supõe que Bataille teria julgado exagerada a exposição de suas confissões íntimas, ou abusivo o seu emprego da interpretação psicanalítica. De qualquer modo, essas reformas aumentaram a distância entre as duas partes da novela $e$, consequentemente, entre "o 'eu' real $e$ o 'eu' do narrador" (Leiris, 2004:34).

10.

"Como Édipo, decifrei o enigma", afirma Bataille; "ninguém o decifrou mais profundamente do que eu". Em um extremo desse processo de deciframento psicanalítico, encontra-se uma novela pornográfica; no outro, os efeitos trágicos da guerra sobre o

\footnotetext{
${ }^{26}$ Por esse motivo provavelmente é que a edição brasileira publicou-o depois, $e$ não antes, da novela: cf. Bataille (2003:95).
} 
cotidiano de uma família francesa comum. Entre ambos, interpõese uma série de elementos subjetivos associados segundo um princípio de variações simbólicas que procura ocultar uma experiência devastadora. A forma empregada para exprimir tal deciframento não é fortuita; ela dirige seu foco sobre os traços mais horrendos, valendo-se inclusive de uma linguagem escatológica, para descrever uma condição humana absolutamente desgraçada, produzida pelo encontro conjuntural entre um indivíduo socialmente ordinário e um conflito bélico de proporções extraordinárias. Para que essa condição pudesse ter sido encarada seriamente, acomodando-se perfeitamente à categoria trágica, foi necessária uma transformação decisiva no sistema classificatório literário, que se pôs em curso a partir da emergência do cristianismo, mas que se concretizou plenamente, por motivos históricos e sociais, apenas na França oitocentista, abolindo a hierarquia entre objetos altos e baixos. Segundo Auerbach (2003), tal hierarquia não era somente literária, mas social, pois enquanto ela confinava o povo comum à comédia, apresentada em estilo grotesco, reservava exclusivamente a tragédia, elaborada em estilo sublime, às grandes figuras. $\mathrm{O}$ principal catalisador dessa mudança no século XIX foram os movimentos revolucionários e suas reações, que tornaram evidente o vínculo indissociável entre todos os seres humanos, estimulando um interesse genuíno, e portanto potencialmente trágico, pelas camadas sociais inferiores, ainda que um resquício de exotismo irrefutavelmente persistisse, amparado pela própria estratificação social ${ }^{27}$. No século seguinte, essa ampliação da escala de vivência humana impediu a apreensão literária completa de uma situação social determinada, estimulando uma fragmentação da realidade que incluía também a perspectiva histórica, de modo que o real já não podia mais ser apreendido senão através da subjetividade.

Em História do olho, a rotina de uma família francesa provinciana, marcada pela enfermidade e pelas adversidades da

${ }^{27}$ Sobre a noção de exotismo em Auerbach, ver Sobral (2018). 
guerra, foi transformada, através de uma série de deslocamentos inconscientes executada pela subjetividade de um de seus membros, em episódios obscenos. Ao mesmo tempo, o trabalho de redação desses episódios orientou-se pelos critérios literários então estabelecidos, permitindo o enquadramento sério, e mesmo trágico, de cenas que em outro momento seriam objeto de escárnio. Nesse percurso, o artifício literário, guiado pelas convenções do gênero pornográfico, expurgou todos os elementos refratários ao livre curso da fantasia, especialmente aqueles que permitiriam localizar a novela em sua situação social e histórica concreta; estes não se encontram ausentes, mas deslocados da narrativa para seus comentários, que os desvendam por meio da psicanálise. É preciso observar enfim que essas distinções não implicam em etapas sucessivas, em uma cronologia, pois a psicanálise ocorreu concomitante à escrita; elas alimentaram-se mutuamente, produzindo benefícios psíquicos e marcando o nascimento de um escritor. É por isso que o deciframento, partindo de detalhes do texto e seguindo a cadeia de associações psíquicas, não apenas conclui que a novela é a expressão disfarçada de uma lembrança dolorosa, como descreve esta em termos literários, isto é, como uma vivência cotidiana trágica, imersa em condições sociais e históricas particulares. Dessa maneira, à luz do trabalho filológico produzido por Auerbach no entreguerras, a fantasia sexual de Bataille revela-se profundamente vinculada a uma conjuntura histórica muito mais ampla, que não apenas selara o destino de seu pai, como subjugara boa parte do mundo e especialmente da Europa.

\section{Referências bibliográficas}

ARAGON, Louis. Le Con d'Irène. S. 1. [Paris], s. n. [René Bonnel], 1928.

ARMEL, Aliette. Michel Leiris. Paris, Fayard, 1997.

AudoIN-RouzeAu, Stéphane \& Becker, Jean-Jacques. (orgs.) Encyclopédie de la Grande Guerre. 1914-1918. Histoire et culture. Paris, Bayard Édition, 2013. 
AuERBACH, Erich. Mimesis. The Representation of Reality in Western Literature. Princeton, Princeton University Press, 2003.

BAtAille, Georges. Fatrasies. La Révolution surréaliste (6), Paris, Gallimard, 1926, pp. 2-3.

BAtAille, Georges. Eil. Documents. Archéologie, beaux-arts, ethnographie, variétés (4), Paris, Jean-Michel Place, 1929, pp. 215218.

BATAILlE, Georges. À propos de Pour qui sonne le glas? d'Ernest Hemingway. In: BATAILlE, Georges. (org.) L'Espagne libre. Paris, Calmann-Lévy, 1946, pp. 120-126.

BAtAille, Georges. Le Bleu du ciel. Paris, Jean-Jacques Pauvert, 1957.

Bataille, Georges. Histoire de l'œil. In: Batallle, Georges. Euvres complètes. I. Premiers écrits. 1922-1940. Paris, Gallimard, 1970a, pp. 7-78, 611-612.

BAtAille, Georges. Appendice. Histoire de l'œil (Nouvelle version). In: Bataille, Georges. Euvres complètes. I. Premiers écrits. 1922-1940. Paris, Gallimard, 1970b, pp. 569-608.

BATAILlE, Georges. L'Ordre de Chevalerie. Conte en vers du XIII ${ }^{e}$ siècle publié avec une introduction et des notes. In: BATAILLE, Georges. Euvres complètes. I. Premiers écrits. 1922-1940. Paris, Gallimard, 1970 c, pp. 99-102.

Bataille, Georges. L'Anus solaire. In: BATAILle, Georges. Euvres complètes. I. Premiers écrits. 1922-1940. Paris, Gallimard, 1970d, pp. 79-86.

Bataille, Georges. Dossier de L'œil pinéal. In: Bataille, Georges. Euvres complètes. II. Écrits posthumes. 1922-1940. Paris, Gallimard, 1970e, pp. 11-47.

Bataille, Georges. Le Petit. In: Bataille, Georges. CEuvres complètes. III. Euvres littéraires. Paris, Gallimard, 1971a, pp. 32-65, 495-500.

Bataille, Georges. Le Bleu du ciel. In: Bataille, Georges. Euvres complètes. III. CEuvres littéraires. Paris, Gallimard, 1971b, pp. 377487, 560-563.

Bataille, Georges. L'Érotisme. In: BATAILle, Georges. Euvres complètes. X. Paris, Gallimard, 1987, pp. 7-270. 
BATAILle, Georges. Choix de lettres. 1917-1962. Paris, Gallimard, 1997.

Bataille, Georges. Histoire de l'oeil. Paris, Jean-Jacques Pauvert, 2001.

BatAille, Georges. História do olho. São Paulo, Cosac Naify, 2003.

BATAILLE, Georges. Romans et récits. Paris, Gallimard, $2004 a$.

BATAILLE, Georges. Le surréalisme au jour le jour. In: BATAILLE, Georges e LEIRIS, Michel. Échanges et correspondances. Paris, Gallimard, 2004b, pp. 51-72.

BrÉCOURT-VIllars, Claudine. René Bonnel, un franc-tireur de l'édition des années folles. Revue de la Bibliothèque Nationale de France (7), Paris, Bibliothèque Nationale de France, 2001, pp. 67-70.

BRETON, André. (org.) Recherches sur la sexualité. La Révolution surréaliste, (11), Paris, Gallimard, 1928, pp. 32-40.

CARAssou, Michel. Sexualité. In: BIRO, Adam e PASSERON, René. (orgs.) Dictionnaire général du surréalisme et de ses environs. Paris, Presses Universitaires de France, 1982, pp. 381-382.

CHAPON, François. Le Peintre et le livre. L'Âge d'or du livre illustré en France. 1870-1970. Paris, Flammarion, 1987.

CHAPSAL, Madeleine. Os escritores e a literatura. Lisboa, Dom Quixote, 1986.

CORON, Antoine. Livres de luxe. In: CHARTIER, Roger e MARTIN, HenriJean. (orgs.) Histoire de l'édition française. Volume 4. Le livre concurrencé. 1900-1950. Paris, Fayard / Cercle de la Librairie, 1991, pp. 425-463.

DARNTON, Robert. The Forbidden Best-Sellers of Pre-Revolutionary France. Nova York, W. W. Norton, 1996.

DurozoI, Gérard. Histoire du mouvement surréaliste. Paris, Éditions Hazan, 2004.

FREUD, Sigmund. A interpretação dos sonhos (1900). São Paulo, Companhia das Letras, 2019.

GINZBURG, Carlo. Sinais. Raízes de um paradigma indiciário. In: GINZBURG, Carlo. Mitos, emblemas, sinais. Morfologia e história. São Paulo, Companhia das Letras, 2002, pp. 143-179. 
GOYATÁ, Júlia Vilaça. Georges Bataille e Michel Leiris: a experiência do sagrado. São Paulo, Humanitas / Fapesp, 2016.

Gregori, Maria Filomena e DíAS-BeníteZ, Maria Elvira. (orgs.) Dossiê: Pornôs. Cadernos Pagu (38), Campinas, Núcleo de Estudos de Gênero. Pagu, 2012, pp. 7-279.

Hemingway, Ernest. Pour qui sonne le glas. Londres, Heinemann \& Zsolnay, 1944.

Hollien, Denis. (org.) Le Collège de Sociologie. 1937-1939. Paris, Gallimard, 1995.

HuNT, Lynn. Introduction: Obscenity and the Origins of Modernity, 15001800. In: HunT, Lynn. (org.) The Invention of Pornography. Obscenity and the Origins of Modernity, 1500-1800. Nova York, Zone Books, 1996, pp. 9-45.

KRUMEICH, Gerd e AudoIN-ROUZEAU, Stéphane. Les batailles de la Grande Guerre. In: AUDOIN-ROUZEAU, Stéphane e BECKER, JeanJacques. (orgs.) Encyclopédie de la Grande Guerre. 1914-1918. Histoire et culture. Paris, Bayard Édition, 2013, pp. 284-285.

LE BOULER, Jean-Pierre. Sur le séjour en Espagne de Georges Bataille (1922): quelques documents nouveaux. Bibliothèque de l'École des Chartes (146), Paris, École des Chartes, 1988, pp. 179-190.

LEIRIS, Michel. Du temps de Lord Auch. In: BATAILLE, Georges e LEIRIS, Michel. Échanges et correspondances. Paris, Gallimard, 2004, pp. 3348.

LORD AuCH [Georges Bataille]. Histoire de l'oeil. Paris, s. n. [René Bonnel], 1928.

LouIS TRENTE [Georges Bataille]. Le Petit. S. 1. [Paris], s. n. [Georges Hugnet], 1934 [1943].

Mandel, Miriam B. Hemingway's Death in the Afternoon. The Complete Annotations. Lanham, MD, Scarecrow Press, 2002.

MARCHAND, Jean-José. Pascal Pia (1903-1979). In: Dictionnaire de la Littérature française. $X X^{e}$ siècle. Paris, Encyclopædia Universalis \& Albin Michel, 2000, pp. 567-568. 
MARCUS, Steven. The Other Victorians. A Study of Sexuality and Pornography in Mid-Nineteenth-Century England. Nova York, Basic Books, 1974.

Masson, André. André Masson en España. 1933-1943. Madri, Electa España, 1993.

MÉTRAuX, Alfred. Rencontre avec les ethnologues. Critique (195-196), Paris, Les Éditions de Minuit, 1963, pp. 673-679.

MoraES, Eliane Robert. Um olho sem rosto. In: BATAILlE, Georges. História do olho. São Paulo, Cosac Naify, 2003, pp. 7-20.

MORAES, Eliane Robert. O corpo impossível. A decomposição da figura humana: de Lautréamont a Bataille. São Paulo, Iluminuras, 2012.

PHILLIPS, John. Old Wine in New Bottles? Literary Pornography in Twentieth-Century France. In: SIGEL, Lisa Z. (org.) International Exposure. Perspectives on Modern European Pornography, 18002000. New Brunswick, NJ, e Londres, Rutgers University Press, 2005, pp. 125-145.

QUIGNARD, Marie-Françoise. Où l'on ne parle pas encore d'Enfer mais d'ouvrages licencieux. In: QUIGNARD, Marie-Françoise e SECKEL, Raymond-Josué. (orgs.) L'Enfer de la Bibliothèque. Éros au secret. Paris, Bibliothèque Nationale de France, 2007a, pp. 27-32.

QUIGNARD, Marie-Françoise. René Bonnel, éditeur clandestin. In: QUIGNARD, Marie-Françoise e SECKEL, Raymond-Josué. (orgs.) L'Enfer de la Bibliothèque. Éros au secret. Paris, Bibliothèque Nationale de France, 2007 b, pp. 355, 358.

RICHARDSON, Michael. Dictionary. In: ADES, Dawn e BAKER, Simon. (orgs.) Undercover Surrealism. Georges Bataille and Documents. Londres e Cambridge, Hayward Gallery / The MIT Press, 2006, p. 92.

ROUDINESCO, Elisabeth. Histoire de la psychanalyse en France. 1. 18851939. Paris, Fayard, 1994.

SAPHIRE, Lawrence e CRAMER, Patrick. André Masson. Catalogue raisonné des livres illustrés. Genebra, P. Cramer, 1994.

SoBRAL, Luís Felipe. Fronteiras da Europa. A corrida de touros vista da Paris literária entre-guerras. Tese de doutorado, Antropologia Social, Unicamp, 2015. 
SoBRAL, Luís Felipe. Os limites do exotismo. Auerbach, a Europa e as touradas. Novos Estudos Cebrap 37(2), São Paulo, Cebrap, 2018, pp. 313-332.

SteVEnSON, Robert Louis. In the South Seas. Being an Account of Experiences and Observations in the Marquesas, Paumotos and Gilbert Islands in the Course of Two Cruises, on the Yacht "Casco" (1888) and the Schooner "Equator" (1889). Londres, Chatto and Windus, 1900.

SuRYA, Michel. Georges Bataille, la mort à l'œeuvre. Paris, Gallimard, 1992.

SURYA, Michel. Georges Bataille, histoire d'un trompe-l'œil. In: QUIGNARD, Marie-Françoise e SECKEL, Raymond-Josué. (orgs.) L'Enfer de la Bibliothèque. Éros au secret. Paris, Bibliothèque Nationale de France, 2007, pp. 370-391.

TEIXEIRA, Vincent. L'œil à l'œuvre: Histoire de l'oeil et ses peintres. Cahiers Bataille (1), Paris, Éditions les Cahiers, 2011, pp. 197-220.

WAIZBORT, Leopoldo. Erich Auerbach e a condição humana. In: ALMEIDA, Jorge de e BADER, Wolfgang. (orgs.) O pensamento alemão no século xx. Grandes protagonistas e recepção das obras no Brasil. Volume 2. São Paulo, Cosac Naify, 2013, pp. 175-217.

ZoRzI, Maria Victória Gaburro. O "Dicionário" de Documents (19291930) e a Antropologia de Georges Bataille. Dissertação de mestrado, Antropologia Social, Universidade de São Paulo, 2013. 